\title{
Resistance of ten common medicinal plants to the root-knot nematode Meloidogyne javanica
}

\author{
S. Ansari', H. Charehgani" and R. Ghaderi
}

Summary A preliminary survey indicated that the root-knot nematode Meloidogyne javanica is widely distributed in the rhizosphere of medicinal plants in Boyer-Ahmad region (Iran). Host suitability of ten species of medicinal plants to $M$. javanica was examined in a pot experiment under controlled greenhouse conditions: alkakengy (Physalis alkekengi L.), chamomile (Matricaria chamomilla L.), English plantain (Plantago lanceolata L.), fennel (Foeniculum vulgare Mill.), garden anchusa (Anchusa italica Retz.), horehound (Marrubium vulgare L.), lovage (Levisticum officinale L.), sorrel (Rumex acetosella L.), thistle (Echinops adenocaulos Boiss.) and woundwort (Stachys pilifera Benth.). According to the scheme of Canto-Saenz, seven species, namely garden anchusa, fennel, horehound, alkakengy, English plantain, woundwort and sorrel can be considered susceptible hosts with gall index $(\mathrm{Gl})>2$ and reproduction factor (RF) > 1, and thistle, lovage and chamomile, can be considered as hyper-susceptible with GI $>2$ and $\mathrm{RF} \leq 1$.

Additional keywords: gall Index, hyper-susceptible, reproduction factor, susceptible

\section{Introduction}

Root exudates of plants contain chemical compounds which attract nematodes to the root or result in repulse, motility inhibition or even their death (Curtis et al., 2009). For example, chlorogenic acid which is subsequently oxidized by the action of host or nematode polyphenol oxidase might inhibit nematode activity and prevent root-knot nematode larvae from penetrating the endodermis into tissues suitable for giant cell production (Hung and Rohde, 1973). Three alkaloids namely sanguinarine, chelerytherine and allocryptopine have shown strong nematicidal activity (Wang et al., 2012). In addition, the phenolic acid compounds are potentially involved in resistance or tolerance of tall fescue (Festuca sp.) (Poaceae) to Pratylenchus scribneri (Pratylenchidae) (Bacetty et al., 2009).

Susceptibility of medicinal plants to parasitic nematodes vary between the spe-

1 Department of Plant Protection, College of Agriculture, Yasouj University, Yasouj, Iran.

2 Department of Plant Protection, School of Agriculture, Shiraz University, Shiraz, Iran.

* Corresponding author: h.charehgani@yu.ac.ir cies, from susceptible (Chinappen et al., 1988; Rhoades, 1988; Mustika, 1992) to resistant (Mukhopadhyaya et al., 1980; Tanda et al., 1989; Haseeb and Butool, 1990; Haroon and Huettel, 1991) (Table 1). Studies by Sivakumar and Vadivelu (1997) on 46 medicinal and aromatic plants showed that Meloidogyne hapla (Heteroderidae) was the predominant nematode species followed by Helicotylenchus indicus (Hoplolaimidae), Pratylenchus coffeae (Pratylenchidae), Tylenchorhynchus martini (Belonolaimidae), Xiphinema americanum (Longidoridae), Scutellonema conicephalum (Hoplolaimidae) and Hemicriconemoides mangiferae (Criconematidae). Root-knot nematodes (Meloidogyne spp.) are serious pests of medicinal and ornamental plants (Haseeb et al., 1984), which, in high population density can affect the quantity and quality of production (Haseeb et al., 1996).

The objective of the present study was to determine the susceptibility of ten common medicinal plants as hosts to the rootknot nematode Meloidogyne javanica (Heteroderidae) under greenhouse conditions based on gall index (GA) and Reproduction Factor (RF), which are two important measures of nematode infestation (Sasser et 
al., 1984) and selection of resistant sources of different plants to root-knot nematodes (Talwana et al., 1997; Cervantes-Flores et al., 2008; Marchese et al., 2010; Mudiope et al., 2012; Gomes et al., 2015; Karuri et al., 2017).

\section{Materials and Methods}

\section{Preparation of nematode inoculum}

Eggs of $M$. javanica were extracted from galled root of tomato (Solanum lycopersicum cv. Early-Urbana) using the sodium hypoclorite method $(\mathrm{NaOCl}$ ) (Hussey and Barker, 1973). Infected roots collected from the greenhouse of Boyer-Ahmad region were chopped to $2-3 \mathrm{~cm}$ pieces and were shaken in the $0.5 \%$ sodium hypochlorite ( $\mathrm{NaO}$ $\mathrm{Cl}$ ) for 90 seconds and poured into a stack of two sieves, with a $75 \mu \mathrm{m}$ aperture size at top followed by a $25 \mu \mathrm{m}$ aperture size. Eggs retained on $25 \mu \mathrm{m}$ aperture size sieve, which were washed quickly to remove all $\mathrm{NaO}$ $\mathrm{Cl}$ and were counted under a stereomicroscope.

\section{Pot experiments}

The experiments were conducted under greenhouse conditions at $28 \pm 4^{\circ} \mathrm{C}$ under 16:8 h (light : dark) photoperiod. Seeds of Physalis alkekengi L. (alkakengy) (Solanaceae), Matricaria chamomilla L. (chamomile) (Asteraceae), Rumex acetosella L. (sorrel) (Polygonaceae), Plantago lanceolata L. (English plantain) (Plantaginaceae), Foeniculum vulgare Mill. (fennel) (Apiaceae), Anchusa italica Retz. (garden anchusa) (Boraginaceae), Marrubium vulgare L. (horehound) (Lamiaceae), Levisticum officina-

Table 1. Degree of resistance (DR) of medicinal plants to the root-knot nematodes Meloidogyne javanica and Meloidogyne incognita (Walker, 1995; Baida et al., 2011).

\begin{tabular}{|c|c|c|c|}
\hline Medicinal plants & $\begin{array}{c}\text { DR to } M \text {. incognita race } 3 \\
\text { (Walker, 1995) }\end{array}$ & $\begin{array}{l}\text { DR to M. incognita } \\
\text { (Baida et al., 2011) }\end{array}$ & $\begin{array}{l}\text { DR to M. javanica } \\
\text { (Baida et al., 2011) }\end{array}$ \\
\hline Anethum graveolens $\mathrm{L}$. & $\mathrm{H}$ & $\mathrm{H}$ & $\mathrm{H}$ \\
\hline Artemisia absinthium L. & $\mathrm{H}$ & - & - \\
\hline Erurca vesicaria L. & $\mathrm{H}$ & - & - \\
\hline Foeniculum vulgare Mill. & $\mathrm{H}$ & - & - \\
\hline Hyssopus officinalis L. & $\mathrm{H}$ & $\mathrm{H}$ & $\mathrm{H}$ \\
\hline Lavandula augustifolia Mill. & $\mathrm{H}$ & - & - \\
\hline Nepeta cataria L & $\mathrm{H}$ & - & - \\
\hline Ocimum basilicum L. & $\mathrm{H}$ & $\mathrm{H}$ & $\mathrm{H}$ \\
\hline Salvia officinalis L. & $\mathrm{H}$ & - & - \\
\hline Thymus vulgaris L. & $\mathrm{H}$ & $\mathrm{H}$ & $\mathrm{H}$ \\
\hline Mikania glomerata Sprengel. & - & $\mathrm{H}$ & $\mathrm{H}$ \\
\hline Pimpinella anisum L. & - & $\mathrm{R}$ & $\mathrm{H}$ \\
\hline Coriandrum sativium $\mathrm{L}$. & $\mathrm{S}$ & - & - \\
\hline Matricaria recutita L. & $\mathrm{S}$ & $\mathrm{S}$ & $\mathrm{S}$ \\
\hline Melissa officinalis L. & $\mathrm{S}$ & - & - \\
\hline Mentha piperita L. & - & - & - \\
\hline Origanum majorana L. & $\mathrm{S}$ & $\mathrm{R}$ & $\mathrm{R}$ \\
\hline Origanum vulgare L. & $\mathrm{S}$ & - & - \\
\hline Rosmarinus officinalis L. & $\mathrm{S}$ & - & - \\
\hline Ruta graveolens L. & $\mathrm{S}$ & $\mathrm{R}$ & $\mathrm{R}$ \\
\hline Satureja hortensis L. & $\mathrm{S}$ & - & - \\
\hline Tanacetum vulgare L. & $\mathrm{S}$ & - & - \\
\hline Tomato (control) & - & $S$ & $S$ \\
\hline Mentha pulegium L. & - & $\mathrm{R}$ & $\mathrm{R}$ \\
\hline Plectranthus barbatus Andr. & - & $\mathrm{R}$ & $\mathrm{R}$ \\
\hline Commiphora myrrha (Nees) Engl. & - & $\mathrm{R}$ & $\mathrm{R}$ \\
\hline Carpobrotus edulis (L.) N.E. Br & - & $\mathrm{R}$ & $\mathrm{R}$ \\
\hline Plectranthus neochilus Schltr. & - & $\mathrm{R}$ & $\mathrm{R}$ \\
\hline
\end{tabular}

$\mathrm{S}=$ Susceptible; $\mathrm{H}=$ Hypersusceptible; $\mathrm{R}=$ Resistance 
le L. Koch (lovage) (Apiaeae), Echinops adenocaulos Boiss. (thistle) (Asteraceae) and Stachys pilifera Benth. (woundwort) (Lamiaceae) were sown in plastic pots $(13 \mathrm{~cm}$ diameter and 10 $\mathrm{cm}$ height) containing $1.5 \mathrm{~kg}$ steam-sterilized sandy loam soil. After 45 days, each plant was inoculated with 5000 eggs + second stage juveniles $\left(J_{2}\right)$ of $M$. javanica as the initial population ( $\mathrm{Pi})$. Inoculation was done by pipetting the egg $+J_{2}$ suspension into 3 holes around the plant root system. The experiment was conducted in a completely randomized design with four replications. The plants were watered daily and were harvested 60 days after inoculation.

The roots were gently washed with tap water and number of eggs in one gram of root were counted according to the procedure developed by Hussey and Barker (1973). One gram of root was stained with acid fuchsine according to the procedure developed by Byrd et al. (1983). The total number of eggs, galls and egg-masses per plant root system was determined by multiplying with the root weight per plant. The number of second stage juveniles $\left(J_{2}\right) / 100$ $\mathrm{cm}^{3}$ of soil was counted after extraction using the modified Baermann pie-pan method (Coyne et al., 2014) and the total number of nematodes in soil was computed by extrapolating the number in $100 \mathrm{~cm}^{3}$ to the volume of soil (1.5 kg).

The final nematode population (Pf) per pot (the total number of nematodes per plant root and the number of $J_{2}$ in soil per pot) were computed and finally, the reproductive factor (RF) of nematode was calculated by dividing the Pf by $\mathrm{Pi}(5,000$ eggs + $\mathrm{J}_{2}$ ). Gall index $(\mathrm{Gl})$ was estimated on a scale of 0 to 5 , where $0=$ no galls; $1=1$ to 2 galls; 2 $=3$ to 10 galls; $3=11$ to 30 galls; $4=31$ to 100 galls; and $5=$ more than 100 galls in the root system (Taylor and Sasser 1978). The degree of resistance of medicinal plant species was allocated according to the modified scheme of Canto-Saenz (Sasser et al., 1984), which is based on $\mathrm{Gl}$ and RF as follows: resistant (GI $\leq 2$, RF $\leq 1)$; tolerant $(\mathrm{GI} \leq 2, \mathrm{RF}>1)$; hypersusceptible $(G I>2, R F \leq 1)$; susceptible $(G I>$ $2, \mathrm{RF}>1)$.

\section{Statistical analysis}

The SAS system V9.1 (SAS Institute Inc., Cary, NC, USA) was used for statistical analyses. Statistical analyses were performed using a one-way analysis of variance ANO$\mathrm{VA}$ and the significant difference between means was determined by Duncan's multiple range test (DMRT) $(p<0.1)$.

\section{Results and Discussion}

Sorrel and horehound had significantly higher number of galls and egg-masses, than the other plant species $(p<0.01)$ (Table 2). The lowest number of galls and egg-masses were recorded in chamomile, garden anchusa and thistle, being significantly lower than those on other plants $(p<0.01)$. The number of eggs in the sorrel root system and the number of $J_{2}$ per pot of garden anchusa were significantly higher than those on the other tested plants. Reproduction factor ranged from 0.05 (in chamomile) to 39.61 (in sorrel) but there was no significant difference among the RFs of chamomile and thistle, lovage, woundwort, english plantain and chamomile $(p<0.01)$ (Tables 2 and 3 ). Therefore, according to our results in Table 3 , the resistance of tested medicinal plants to infection by $M$. javanica can be ranked as follows, according to the Canto-Saenz's scheme (Sasser et al., 1984): thistle (E. adenocaulos), lovage (L. officinale) and chamomile ( $M$. chamomilla) are classified as hypersusceptible, showing significant damage (Gl $>2$ ) while the RF remains below 1. Garden anchusa ( $A$. italica), fennel ( $F$. vulgare), horehound (M. vulgare), alkakengy ( $P$. alkeken$g i)$, english plantain ( $P$. lanceolata), woundwort (S. pilifera) and sorrel (R. acetosella) are ranked as susceptible, with heavy galling (Gl $=5$ ) and high reproduction factors (RF $>2$ ). Sorrel and horehound are the most susceptible hosts with high reproduction factors ( $R F=39.61$ and 20.08, respectively).

Our findings on chamomile, M. chamomilla, to M. javanica (hyper-susceptible host) were similar to those by Baida et al. (2011) on susceptibility of Matricaria recutita L., while 
Table 2. Mean population indices of the root-knot nematode Meloidogyne javanica on ten species of medicinal plants, 60 days after inoculation under greenhouse conditions.

\begin{tabular}{l|c|c|c|c}
\hline Medicinal plants & $\begin{array}{c}\text { Number of } \mathrm{J}_{2} \\
\text { in soil }\end{array}$ & $\begin{array}{c}\text { Number of } \\
\text { eggs/root }\end{array}$ & $\begin{array}{c}\text { Number of } \\
\text { egg-masses/root }\end{array}$ & $\begin{array}{c}\text { Number of } \\
\text { galls/root }\end{array}$ \\
\hline Physalis alkekengi L. & $9525 \pm 35.18^{\mathrm{c}}$ & $19514 \pm 356^{\mathrm{c}}$ & $148 \pm 5.10^{\mathrm{cd}}$ & $161 \pm 6.03^{\mathrm{de}}$ \\
Matricaria chamomilla L. & $56 \pm 7.18^{\mathrm{f}}$ & $184 \pm 2.73^{\mathrm{e}}$ & $14 \pm 1.79^{\mathrm{e}}$ & $21 \pm 1.64^{\mathrm{f}}$ \\
Rumex acetosella L. & $37958 \pm 859^{\mathrm{b}}$ & $176719 \pm 6948^{\mathrm{a}}$ & $786 \pm 82.61^{\mathrm{a}}$ & $801 \pm 82.85^{\mathrm{a}}$ \\
Plantago lanceolata & $3143 \pm 42.65^{\mathrm{e}}$ & $9306 \pm 59^{\mathrm{de}}$ & $344 \pm 5.67^{\mathrm{b}}$ & $365 \pm 5.43^{\mathrm{b}}$ \\
Foeniculum vulgare Mill. & $6619 \pm 35.91^{\mathrm{d}}$ & $5104 \pm 94.58^{\mathrm{e}}$ & $258 \pm 6.57^{\mathrm{bc}}$ & $287 \pm 6.69^{\mathrm{bc}}$ \\
Anchusa italica Retz. & $72380 \pm 244^{\mathrm{a}}$ & $241 \pm 8.95^{\mathrm{e}}$ & $98 \pm 2.81^{\mathrm{de}}$ & $109 \pm 4.32^{\mathrm{def}}$ \\
Marrubium vulgare L. & $5670 \pm 66.24^{\mathrm{d}}$ & $99109 \pm 1901^{\mathrm{b}}$ & $688 \pm 20.14^{\mathrm{a}}$ & $734 \pm 27.78^{\mathrm{a}}$ \\
Levisticum officinale L. & $640 \pm 36.51^{\mathrm{f}}$ & $3411 \pm 64^{\mathrm{e}}$ & $156 \pm 6.51^{\mathrm{cd}}$ & $165 \pm 5.09^{\mathrm{de}}$ \\
Echinops adenocaulos Boiss. & $0 \pm 0^{\mathrm{f}}$ & $364 \pm 10.27^{\mathrm{e}}$ & $16 \pm 3.20^{\mathrm{e}}$ & $63 \pm 10.26^{\mathrm{ef}}$ \\
Stachys pilifera Benth. & $919 \pm 35.9^{\mathrm{f}}$ & $15506 \pm 487^{\mathrm{cd}}$ & $190 \pm 7.55^{\mathrm{cd}}$ & $197 \pm 8.12^{\mathrm{cd}}$ \\
\hline
\end{tabular}

Values in the same column followed by the same letter(s) are not significantly different $(p<0.01)$ based on Duncan's multiple range test (DMRT). Values are means \pm standard error.

Table 3. Designation of resistance of ten species or aromatic plants to the root-knot nematode Meloidogyne javanica based on reproduction factor and gall index.

\begin{tabular}{|c|c|c|c|}
\hline Medicinal plants & Reproduction factor & Gall Index & Resistance \\
\hline Physalis alkekengi L. & $5.56 \pm 0.08^{c}$ & 5 & $\mathrm{~S}$ \\
\hline Matricaria chamomilla L. & $0.05 \pm 0.002^{d}$ & 3 & $\mathrm{H}$ \\
\hline Rumex acetosella L. & $39.61 \pm 2.92^{a}$ & 5 & $S$ \\
\hline Plantago lanceolata & $2.44 \pm 0.006^{c d}$ & 5 & $\mathrm{~S}$ \\
\hline Foeniculum vulgare Mill. & $2.28 \pm 0.03^{\mathrm{cd}}$ & 5 & $\mathrm{~S}$ \\
\hline Anchusa italica Retz. & $5.19 \pm 0.018^{c}$ & 5 & $\mathrm{~S}$ \\
\hline Marrubium vulgare L. & $20.08 \pm 0.38^{b}$ & 5 & $S$ \\
\hline Levisticum officinale L. & $0.30 \pm 0.0042^{d}$ & 5 & $\mathrm{H}$ \\
\hline Echinops adenocaulos Boiss. & $0.07 \pm 0.002^{d}$ & 4 & $\mathrm{H}$ \\
\hline Stachys pilifera Benth. & $3.16 \pm 0.10^{\mathrm{cd}}$ & 5 & $\mathrm{~S}$ \\
\hline
\end{tabular}

Values in the same column followed by the same letter(s) are not significantly different $(p<0.01)$ based on Duncan's multiple range test (DMRT). Values are means \pm standard error.

Resistance based on Sasser et al. (1984): S = Susceptible; H = Hypersusceptible

Walker (1995) considered chamomile a susceptible host. Fennel was found to be a susceptible host whereas according to Walker (1995) is hyper-susceptible to $M$. incognita race3.

The authors are grateful for financial support from Yasouj University, Iran.

\section{Literature Cited}

Bacetty, A.A., Snook, M.E., Glenn, A.E., Bacon, C.W., Nagabhyru, P. and Schardl. C.L. 2009. Toxicity of endophyte-infected tall fescue alkaloids and grass metabolites on Pratylenchus scribneri. Phytopatology, 99(12): 1336-1345.

Baida, F.C., Santiago, D.C., Ilkiu Vidal, L. H., Baida, L.C. and Stroze, C. T. 2011. Medicinal plants hosting ability for nematode $M$. javanica and $M$. incognita. Nematropica, 41(1): 10-153.

Byrd, D.W., Kirkpatrik, T. and Barker, K.R. 1983. An improved technique for cleaning and staining 
plant tissues for detection of nematodes. Journal of Nematology, 15: 142-143.

Cervantes-Flores, J.C., Yencho, G.C., Pecota, K.V., Sosinki, B. and Mwanga, R.O.M., 2008. Detection of quantitative trait loci and inheritance of rootknot nematode resistance in sweetpotato. Journal of the American Society for Horticultural Science, 133: 844-851.

Chinappen, M., Jokhun, P. and Lamberti, F. 1988. A decline in thyme associated with Rotylenchulus parvus in Mauritius. Nematologia Mediterranea, 16: 233-234.

Coyne, D., Nicol, J. and Claudius-Cole, A. 2014. Practical Plant Nematology: Field and Laboratory Guide, 2nd edition. Cotonou: IITA, $82 \mathrm{p}$.

Curtis, R.H.C., Robinson, A.F and Perry, R.N. 2009. Hatch and host location. In Perry, R.N., Moens, M. and Starr, J.I. (eds). Root-knot nematodes. UK: CAB International. Wallingford, p.139-155

Gomes, J.A.A., Andrade Junior, V.C., de Oliveira, C.M, Azevedo, A.M., Maluf, W.R. and Gomes, L.A.A. 2015. Resistance of sweetpotato clones to Meloidogyne incognita race 1 and 3. Bragantia, 74 (3): 291-297.

Haroon, S. and Huettel, R.N. 1991. Induced hatching and juvenile mortality caused by some medicinal plants to soybean cyst nematodes. Phytopathology, 81: 702 (Abstr.)

Haseeb, A. and Butool, F. 1990. Evaluation of nematicidal properties in some members of the family Lamiaceae. International journal of nematology. Network Newsletter, 7: 24-28.

Haseeb, A., Pandey, R. and Husain, A. 1984. Some new host records of the root-knot nematode, Meloidogyne incognita (Kofoid and White, 1919) Chitwood, 1949. Current Science, 53: 1151-1152.

Haseeb, A., Shukla, P.K. and Butool, F. 1996. Relationship between initial population density of Meloidogyne incognita and growth, oil yield and biochemical changes in plants of Ocimum canum. Nematropica, 26: 181-185.

Hung, C.L and Rohde, R.A. 1973. Phenol accumulation related to resistance in tomato to infection by root-knot and lesion nematodes. Journal of Nematology, 5(4): 253-258.

Hussey, R.S. and Barker, K.R. 1973. A comparison of methodes of collecting inocula of Meloidogyne spp., including a new technique. Plant Disease Reporter, 57: 1025-1028.

Karuri, H.W., Olago, D., Neilson, R., Mararo, E and Vilinger, J. 2017. A survey of root-knot nematodes and resistance to Meloidogyne incognita in sweet potato varieties from Kenyan fields. Crop Protection, 92: 114-121.
Marchese, A., Maluf, W.R., Goncalves Neto, A.C., de Sousa Goncalves R.J. and Gomes, L.A.A. 2010. Selecao de clones de batata-doce resistantes a Meloidogyne incognita raca 1. Pesquisa Agropecuária Brasileira, 45 (9): 997-1004.

Mudiope, J., Coyne, D.L., Adipala, E. and Talwana, H.A.L. 2012. Damage to yam (Dioscorea spp.) by root-knot nematode (Meloidogyne spp.) under field and storage condition in Uganda. Nematropica, 42: 137-145.

Mukhopadhyaya, M.C., Das, T.K., Chattopadhyay, P.R. and Bose, T. 1980. Control of root-knot nematode, Meloidogyneincognita with Typhonium tribolatum, an annual herb. Nematologica, 26: 277-280.

Mustika, I. 1992. Effects of Meloidogyne incognita and Fusarium solani on black pepper (Piper nigrum L.). Industrial Crops Research Journal, 4: 7-13.

Rhoades, H.L. 1988. Effects of several phytoparasitic nematodes on the growth of basil, Ocimum basilicum. Annals of Applied Nematology, 2: 22-24.

Sasser, J.N., Careter, C.C. and Hartman, K.M. 1984. Standardization of host suitability studies and reporting of resistant to root-knot nematodes. USA: North Carolina state Graphics, Raleigh, 7 p.

Sivakumar, M. and Vadivelu, S. 1997. Parasitic nematodes associated with medicinal and aromatic plants. Indian Journal of Nematology, 27: 58-62.

Talwana, H.L., Speijer, P., Adipala, E. and Maslen, N.R. 1997. Evaluation of cassava for reaction to rootknot nematode (Meloidogyne spp.) in Uganda. African Journal of Plant Protection, 6: 125-134.

Tanda, A.S., Atwal, A.S. and Bajaj, Y.P.S. 1989. In vitro inhibition of root-knot nematode Meloidogyne incognita by sesame root exudate and its amino acids. Nematologica, 35: 115-124.

Taylor, A.L. and Sasser, J.N. 1978. Biology, identification and control of root-knot nematodes (Meloidogyne species). USA: North Carolina State University and the U.S.Agency for Internayional Development, $111 \mathrm{p}$.

Walker, J.T. 1995. Garden herbs as hosts for southern root knot nematode, Meloidogyne incognita race 3. Hortscience, 30(2): 292-293.

Wang, K., Luo, C., Liu, H., Xu, J., Sun, W. and Zhou, L. 2012. Nematicidal activity of the alkaloids from Macleaya cordata against certain nematodes. African Journal of Agricultural Research, 7(44): 5925-5929.

Received: 12 July 2018; Accepted: 10 December 2018 


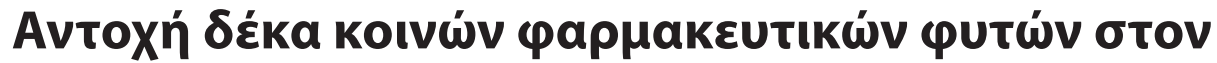

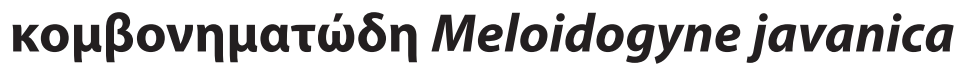

\author{
S. Ansari, H. Charehgani kaı R. Ghaderi
}

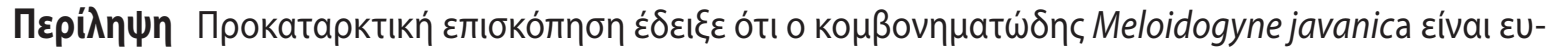

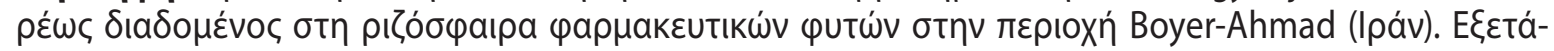

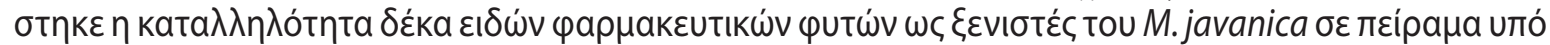

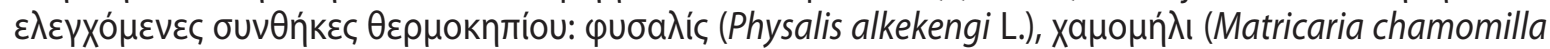

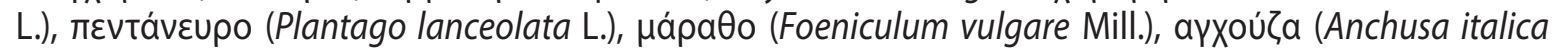

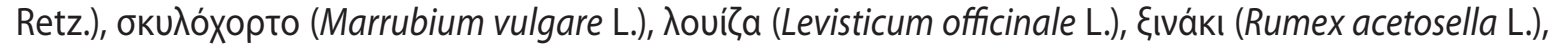

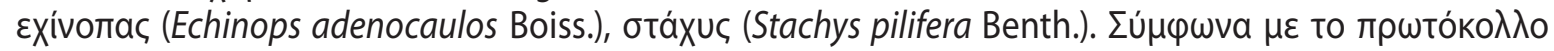

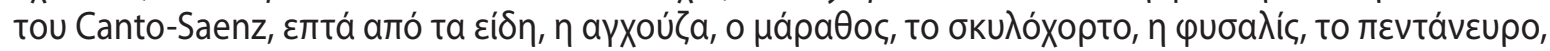

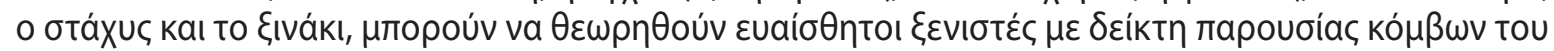

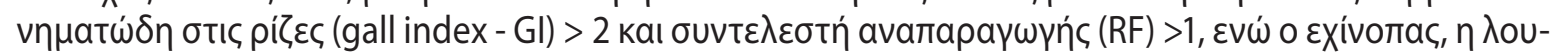

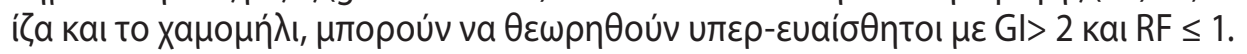

Hellenic Plant Protection Journal 12: 6-11, 2019 